Journal of Southeast Asian

\title{
Selected Poems
}

Toon Souksada Phapphayboun

Western Piedmont Community College, tphapphayboun@wpcc.edu

\section{Recommended Citation}

Phapphayboun, Toon Souksada (2011) "Selected Poems," Journal of Southeast Asian American Education and Advancement: Vol. 6 : Iss. 1, Article 22.

DOI: $10.7771 / 2153-8999.1038$

Available at: https://docs.lib.purdue.edu/jsaaea/vol6/iss1/22

This document has been made available through Purdue e-Pubs, a service of the Purdue University Libraries. Please contact epubs@purdue.edu for additional information.

This is an Open Access journal. This means that it uses a funding model that does not charge readers or their institutions for access. Readers may freely read, download, copy, distribute, print, search, or link to the full texts of articles. This journal is covered under the CC BY-NC-ND license. 


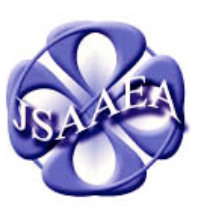

Volume 6 (2011)

\section{Journal of Southeast Asian American Education \& Advancement}

WWW.JSAAEA.org
A peer-reviewed scholarly journal published by the National Association for the Education \& Advancement of Cambodian, Laotian, and Vietnamese Americans (NAFEA)

\title{
Selected Poems
}

\author{
by \\ Toon Souksada Phapphayboun \\ Western Piedmont Community College
}

\section{Adaptability}

Home is ...

The first house my father built

The school I learned my kor, gkor, khor

My childhood pals who are still pals

A dinner table where my family gathers

Home is ...

A bamboo shack that sleeps eight

A communal bathroom that becomes my haven of thoughts

A place where strangers become family

Where what little we share turns plentiful

Home is ...

A dormitory where my individualism begins

The first car bought with my burger-flipping wages

The degrees I earned with bloody beads of sweat and tear

An office that houses all the many journeys

Home is ...

A gathering of common hearts and souls

A grouping of common cause and shared vision

A conference of ideas and exchanges

A culmination of collective devotion

Home is ...

Laos

Thailand

The Philippines

The USA

Home is not where I hang my heart, not really

Rather, it's a heart that adapts peacefully.

\footnotetext{
(C)

SOMERIGHISRESEREED Readers are free to copy, display, and distribute this article, as long as the work is attributed to the author(s) and the Journal of Southeast Asian American Education \& Advancement, it is distributed for noncommercial purposes only, and no alteration or transformation is made in the work. More details of this Creative Commons license are available at http://creativecommons.org/licenses/by-nc-nd/3.0/. All other uses must be approved by the author(s) or JSAAEA.
} 


\section{Forbidden Fruits}

In writing about food, I sat for many days trying to recollect my memories to share with the group. I started thinking about the format, the style, and basically doing all I could to find my muse to start writing, but after many scrunched-up balls of paper, I was still clueless on what I wanted to share. But then at 1 am on June 13th, it hit me. I realized that I was looking in the wrong place; the fondest memories about food were buried deep down. You see, the food that fed my soul lived across the Mekong River. Here, my friends, is where my story actually begins:

The time was 1978-1979, a couple of years after the sudden government change in Laos. Among the many changes were the new school rules. My school, Matthayuom Sikhay (Sikhay Junior High School) was no exception. All students must abide by the rules, one of which is uniforms. We must wear a white top and a black/blue bottom; all boys must wear their hair short, and all girl must wear their hair long and tie it in a pony tail. Boys must wear black/blue trousers, and girls must wear a black/blue siin (a traditional Lao wear for women.) And, all students must tuck in their shirts. Even with all the restrictions, the uniform rule was easy to follow, but there was one rule that was hard to obey-no food or drink was allowed on campus. Hence, our schedule was broken into two sessions: the morning session was for academia, such as writing, history, social etiquette, and the afternoon session was for extracurricular activities, such as gardening, peer evaluation, and classroom decorations.

These two sessions were divided by our two-hour lunch break. As you can see, it was hard not to bring edible items for the afternoon session, especially when some of us decided to take a quick swim in the Mekong River instead of eating lunch. Since we had to rush right back to school after our little swim, we had to bring something to snack on in order to keep our young minds active and awake. Since no vivirins and no McDonald's were available for a quick bite, we turned to nature to keep ourselves awake in the afternoon sessions. Specifically in my classroom, we organized the student body into two groups: one would bring jeo (the sauce) and the other would bring maak muaang diep (green mangoes) or maak kaam diep (green tamarinds) to campus. This perfect combination of revival pills and our own version of gourmet lunch must be smuggled into our battle field - our campus, for if caught all would be confiscated, and the smugglers would be strictly and publicly punished as a reminder, a threat to deter students from committing the same crime. Even with such risks and struggles, we somehow managed to unite our jeo with its allies_-maak muaang and maak kaam diep. We were brave and efficient soldiers; no one in our classroom ever got caught, and nothing was ever confiscated. So, regularly before parting each other after the morning session, the designated person in the two groups would utter these words, "Ya leum aan naan der!" (Don't forget the thing!) Employing careful strategies, we were able to enjoy our perfected lunch daily. 
Nowadays, it is so easy for me to make jeo to dip my mangoes and tamarinds in, but this dish does not taste the same. Is it because the mangoes and the tamarinds are on American soil? Or, is it because the ingredients for my jeo are too foreign? At first, I thought so, but when I visited Laos in 1988, I tried to create the same jeo, and I tried to find the just right tamarinds and mangoes, but I never found it, that perfect combination that I had in 1978-1979. My tongue continues to salivate for that perfect mix - the spicy sweetness of jeo and the just right sourness of the fruits. My taste buds search on for the illegal jeo and the forbidden fruits that I luxuriously enjoyed at Matthayuom Sikhay.

I still vividly see the equally sliced-in-half maak kaam diep with their seeds removed, and the jeo filled each of the compartments where the seeds used to be; I clearly see the thickly chopped slices of maak muaang diep being dipped in the condensed, syrupy jeo.

Is it possible that such an unforgettable, flavorful cuisine could only be found one moment in time? My search continues!

\section{Soy y Estoy}

At birth, I question my existence.

I question my contribution.

I question my significance.

I question my destination.

At worst, I do not exist.

I do not contribute.

I do not signify.

I do not destine.

At best, I am existing.

I am contributing.

I am signifying.

I am destined.

Humanly, I am deep and shallow.

I am witty and naive.

I am saintly and sinful.

I am just a simple river. 


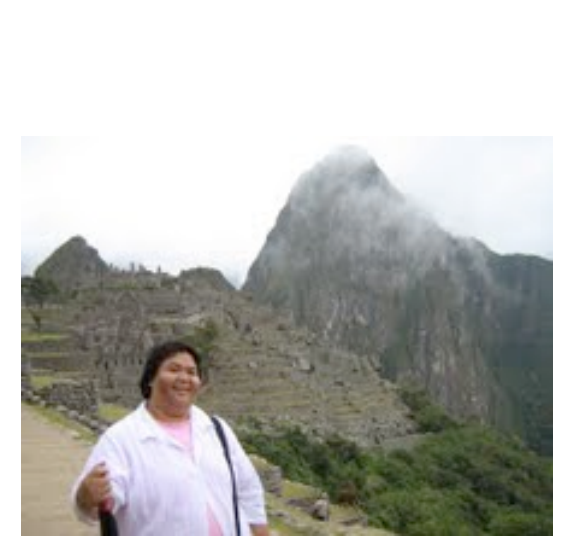

\begin{abstract}
About the Author
Toon Phapphayboun is an English and Spanish faculty member at Western Piedmont Community College in Morganton, North Carolina. She received her Bachelor of Art degree in English/American Literature at the University of California, Santa Cruz and a Master of Art degree from California State University, Dominguez Hills in Carson, California. She also has eighteen graduate Spanish hours from Appalachian State University in Boone, North Carolina. Aside from teaching, she spends time with her family, particularly mentoring her niece
\end{abstract} and nephews in their educational endeavors, and she is passionate about giving back to the community what it has given her. Currently, she is a member of a scholarship review board for Lao American Women Association of Washington, D.C. 


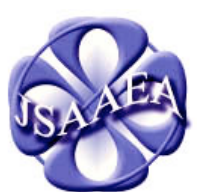

Volume 6 (2011)

\section{Journal of Southeast Asian American Education \& Advancement}

\author{
WWW.JSAAEA.org
}

\section{Editor}

Dr. Wayne E. Wright

University of Texas, San Antonio

\section{Associate Editors}

Dr. Chhany Sak-Humphry

University of Hawaii

Dr. KimOanh Nguyen-Lam

California State University, Long Beach

Book Review Editor

Dr. Vichet Chhuon

University of Minnesota

\section{Creative Works Editor}

Bryan Thao Worra

Lao Assistance Center

Special Advisor

Gregory Green

Curator, Echols Collection on Southeast Asia, Cornell University Library

Journal Manager

Sovicheth Boun

University of Texas, San Antonio
A peer-reviewed

scholarly journal published by the

National Association

for the Education \&

Advancement of

Cambodian, Laotian,

and Vietnamese

Americans (NAFEA)

Comments and questions for the editorial staff may be directed to jsaaea@lists.sis.utsa.edu

\section{Editorial Review Board}

\author{
Dr. Steve Arounsack \\ California State University, Stanislaus \\ Dr. Phala Chea \\ Lowell Public Schools \\ Dr. Loan Dao \\ Cancer Prevention Institute of California \\ Dr. Sophal Ear \\ U.S. Naval Postgraduate School \\ Dr. Nancy H. Hornberger \\ University of Pennsylvania \\ Dr. Peter Nien-Chu Kiang \\ University of Massachusetts, Boston
}

Dr. Carl L. Bankston III

Tulane University

Dr. George Chigas

University of Massachusetts, Lowell

Dr. Changming Duan

University of Missouri, Kansas City

Dr. Jeremy Hein

University of Wisconsin - Eau Claire

Dr. Samlong Inthaly

Minneapolis Public Schools

Dr. Kevin K. Kumashiro

University of Illinois, Chicago 


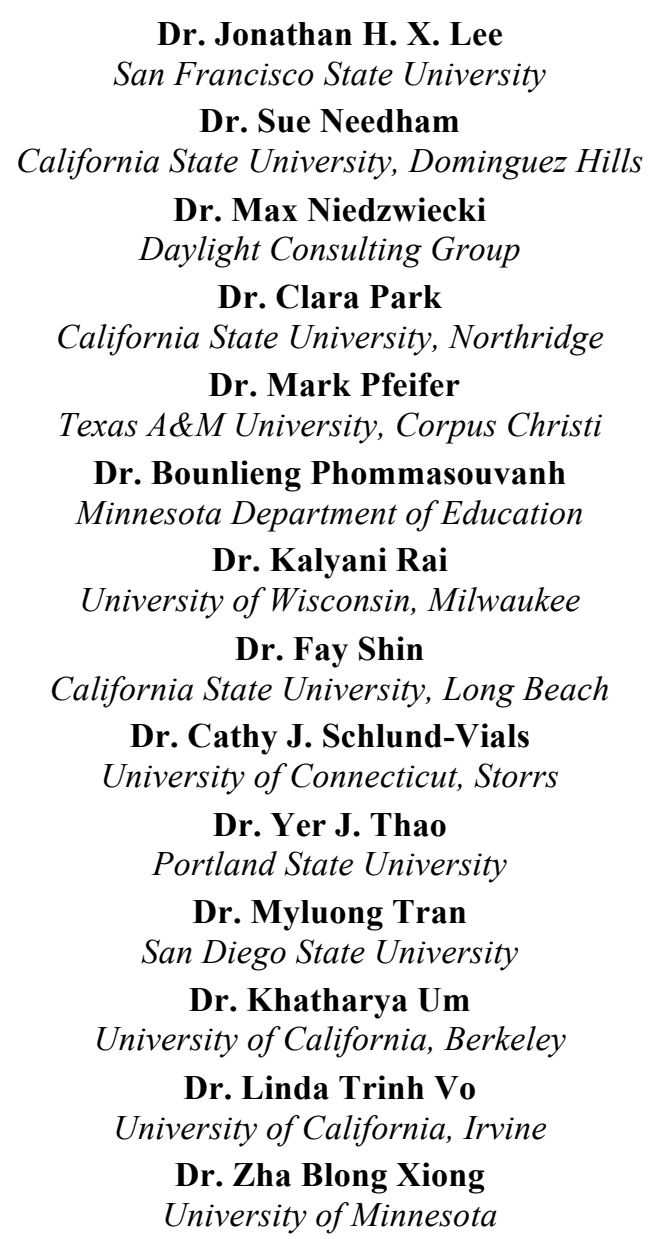

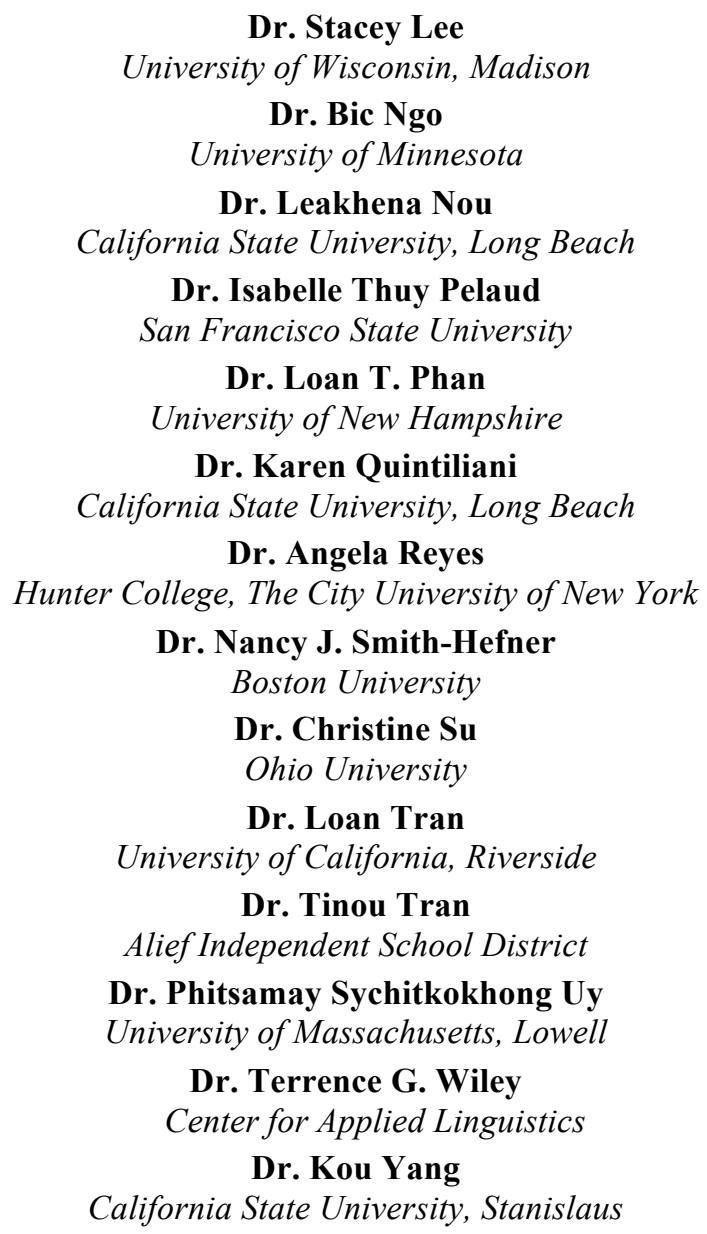

Dr. Stacey Lee

University of Wisconsin, Madison

Dr. Bic Ngo

University of Minnesota

Dr. Leakhena Nou

California State University, Long Beach

Dr. Isabelle Thuy Pelaud

San Francisco State University

Dr. Loan T. Phan

University of New Hampshire

Dr. Karen Quintiliani

California State University, Long Beach

Dr. Angela Reyes

Hunter College, The City University of New York

Dr. Nancy J. Smith-Hefner

Boston University

Dr. Christine Su

Ohio University

Dr. Loan Tran

University of California, Riverside

Dr. Tinou Tran

Alief Independent School District

Dr. Phitsamay Sychitkokhong Uy

University of Massachusetts, Lowell

Dr. Terrence G. Wiley

Center for Applied Linguistics

Dr. Kou Yang

California State University, Stanislaus

\section{Doctoral Student Editorial Review Board}

\author{
Keo Chea-Young \\ University of Pennsylvania \\ Ketmani Kouanchao \\ California State University, Fullerton \\ Polinda Keo \\ University at Albany \\ Ravy Lao \\ University of California, Santa Barbara \\ Thien-Huong Ninh \\ University of Southern California \\ Malaphone Phommasa \\ University of California, Santa Barbara \\ Rassamichanh Souryasack \\ University of California, Santa Barbara \\ Alisia Tran \\ University of Minnesota \\ Silvy Un \\ University of Minnesota
}

\author{
Annie BichLoan Duong \\ San Joaquin County Office of Education \\ Peter Tan Keo \\ Columbia University \\ Ha Lam \\ Arizona State University \\ Monirith Ly \\ Texas State University-San Marcos \\ Giang Pham \\ University of Minnesota \\ Vanna Som \\ Harvard University \\ Somongkol Teng \\ University of Minnesota \\ Krissyvan Truong \\ Claremount Graduate University \\ Yang Sao Xiong \\ University of California, Los Angeles
}

